Ius Matrimoniale 32 (2021) $\mathrm{nr} 1$

ISSN 1429-3803; e-ISSN 2353-8120

DOI: http://doi.org/10.21697/im.2021.32.1.03
Artykuł jest udostępniany na zasadach licencji Creative Commons (CC BY-ND 4.0 Międzynarodowe) https://creativecommons.org/licenses/by-nd/4.0/deed.pl

${ }_{\text {open }} \mathcal{C}_{\text {access }}(\mathrm{C}) \bigodot_{\mathrm{BY}}$

\title{
Zaburzenia nastroju jako przyczyna niezdolności osoby do podjęcia istotnych obowiązków małżeńskich
}

Mood disorders as the cause of the inability of a person to assume the essential obligations of marriage

\author{
Bartosz Nowakowski \\ Wydział Nauk Społecznych UPH w Siedlcach \\ ORCID: 0000-0002-7182-4600 \\ e-mail: bartosz.nowakowski@uph.edu.pl
}

Streszczenie: W artykule omówiono wpływ zaburzeń nastroju na niezdolność osoby do podjęcia istotnych obowiązków małżeńskich. Najpierw autor przedstawia dwa podstawowe typy omawianego zjawiska: typ depresyjny i typ maniakalny. Następnie aplikuje omówione zjawisko do kanonicznego prawa małżeńskiego, dotyczącego procesów o stwierdzenie nieważności małżeństwa.

Słowa kluczowe: zaburzenia nastroju, depresja, mania, melancholia, nieważność małżeństwa

Abstract: The article discusses the influence of mood disorders on the inability of a person to assume the essential obligations of marriage. First, the author presents two basic types of the phenomenon in question: the depressive type and the manic type. Then he applies them to the canonical matrimonial law in the matter of declaring marriage nullity.

Keywords: mood disorders, depression, mania, melancholy, marriage nullity

Treść: Wstęp. 1. Punkt wyjścia. 2. Typ melancholijny, depresyjny. 3. Typ maniakalny. 4. Ocena kanoniczna zjawiska. Zakończenie.

\section{Wstęp}

Nastrój jest sposobem odczuwania i uzewnętrzniania - przez człowieka - zjawisk, uczuć, emocji, temperamentu i charakteru. 
Postrzegany jest jako powszechny i unitarny dla ogółu ludzkości ${ }^{1}$, jako usposobienie umysłu zdolne do emocjonalnego ubarwienia życia. Jednocześnie jest rzeczywistością zmienną, niestabilną, oscylującą od stanu smutku do chwil euforii. Oscylacje te są normalne tak długo, jak długo pozostają w kontekstualnym odniesieniu do środowiska i doświadczeń przeżywanych przez ludzi. Sama bowiem zmiana nastroju nie jest warunkiem wstępnym do zdiagnozowania zaburzeń nastroju, gdyż epizody te są stale obecne w życiu ludzi. Natomiast stany patologiczne występują wtedy, gdy pojawia się niezgodność z sytuacją życiową. Innymi słowy, tym co odróżnia sytuacje normalne od nieadaptacyjnych, jest jakość i trwałość objawów w porównaniu z osobistym kontekstem, w którym one występują. Czasami granica między sytuacją normalną a patologiczną jest bardzo cienka ${ }^{2}$, co tym samym stawia wysokie wymagania rozeznania przypadku przez osoby zaangażowane w ocenę ważności/nieważności małżeństwa.

W kontekście podjętego zagadnienia trudności pojawiają się już praktycznie na płaszczyźnie terminologicznej. Użyte w temacie artykułu określenie „zaburzenia nastroju” nie wywodzi się bowiem z żadnej klasyfikacji zaburzeń mentalnych i jako takowe nigdy nie zostało sklasyfikowane. Znaczy tyle, na ile wskazuje treść użytych terminów, a więc zbiór dookreślonych zaburzeń mentalnych, w których występują zaburzenia nastroju. W takim też rozumieniu w orzecznictwie Roty Rzymskiej można spotkać się zarówno z określeniami: typ maniakalny, typ depresyjny, typ depresyjno-maniakalny, typ

1 Por. T. Cantelmi, M. Aiello, La persona umana: concetto psicologico e maturità affettiva, w: A. Amati, L'immaturità psico-affettiva e matrimonio canonico, Studi Giuridici LXXXV, Città del Vaticano 2009, s. 97.

2 Por. S. CAlicchio, Depresja i dystrybucje humoryczne: zrozumienie podstawowych mechanizmów, 2020, s. 6-7. 
melancholijny (depresja, mania, melancholia) ${ }^{3}$ lub w nowszym orzecznictwie $\mathrm{z}$ zastosowaniem terminu: zaburzenia nastroju (disturbi dell'umore) $)^{4}$.

\section{Punkt wyjścia}

W kontekście naszych rozważań nad wpływem nastroju na zdolność podmiotu do wyrażenia ważnej zgody małżeńskiej należy w pierwszej kolejności odnieść się do podziału wprowadzonego przez T. Cantelmi i M. Aiello, którzy to autorzy rozróżniają tzw. nastrój eutymiczny, w którym podmiot reaguje i kontaktuje w sposób zrównoważony, elastyczny i zgodny z bodźcami zewnętrznymi, i nastrój patologiczny, w którym przeciwnie - podmiot jest stały, nie podlega zmianom w relacji do okoliczności zewnętrznych, bodźców, w powiązaniu z nimi ${ }^{5}$.

W obrazie nastroju patologicznego klasyfikacja DSM-5 wyróżnia dwie główne grupy zaburzeń: zaburzenia depresyjne, których głównym komponentem jest depresja, oraz zaburzenia afektywne $d$ wubiegunowe i pokrewne, w których występuje mania ${ }^{6}$. K. Leonhard już w drugiej połowie XX w. wykazał, że cechy osobowości osób $\mathrm{z}$ dwubiegunowym przebiegiem choroby (typ maniakalny) ujawniaja istotne różnice $\mathrm{w}$ porównaniu $\mathrm{z}$ osobami $\mathrm{z}$ chorobą afektywną jednobiegunową (typ depresyjny). Do podobnych wniosków doszli również

3 Por. c. Alwan, 13.02.1997, RRDec., vol. LXXXIX, s. 88-102; c. Doran, 4.03.1993, RRDec., vol. LXXXV, s. 108-120; c. BURke, 12.12.1996, RRDec., vol. LXXXVIII, s. 803-817; c. BRUno, 31.01.1997, RRDec., vol. LXXXIX, s. 70-87; c. Civili, 19.06.1996, RRDec., vol. LXXXVIII, s. 468-479; c. Monier, 5.02.1999, RRDec., vol. XCI, s. 48-57.

4 Por. c. Stankiewicz, 27.02.2003, RRDec., vol. XCV, s. 107-121; c. StankieWICZ, 23.03.2000, RRDec., vol. XCII, s. 249-267; c. TurnAtURI, 20.02.1998, RRDec., vol. XC, s. 84-99.

5 Por. T. Cantelmi, M. Aiello, La persona umana: concetto psicologico..., s. 97.

6 Por. E. Stopani, Disturbi dell'umore, https://www.ipsico.it/sintomi-cura/ disturbi-dellumore (dostęp 15.02.2020 r.); M. Luigia, Disturbi dell'umore. Sintomi, cura e classificazione, https://www.ospedalemarialuigia.it/disturbi-dell-umore/cosa-sono-disturbi-umore-dsm-v (dostęp 15.02.2020 r.); Zaburzenia nastroju, https:// cnx.org/contents/co3wu-B_@1.1:Zj5vy_rd@2/15-7-Zaburzenia-nastroju (dostęp 15.02.2020 r.). 
w tym samym czasie wybitni psychiatrzy J. Angst i C. Perris, którzy stwierdzili liczne istotne odrębności w przebiegu obu typów zaburzeń afektywnych, wykazali, że z punktu widzenia genetycznego oba schorzenia różnią się istotnie ${ }^{7}$. Przedmiotowy podział przyjmiemy również jako schemat dalszych naszych analiz.

Nie należy jednak zapominać, że klasyfikacja zaburzeń nastroju jest nadal kwestią otwartą, złożoną i problematyczną. Kategorie diagnostyczne zdefiniowane są jako umownie przyjęte podgrupy wyodrębnione w oparciu o diagnozę ilości objawów kwalifikujących, czas trwania, poziom dystresu i dysfunkcjonalności, a także przebieg (np. dni, w których występują objawy w ciągu określonej jednostki czasu, zazwyczaj roku lub dwóch lat). Z całą pewnością psychiatria jest jeszcze daleko od ostatecznego ujęcia wymiarowego. Biorąc pod uwagę niedoskonałość w/w podziału na jednobiegunowość i dwubiegunowość (w tym ukrytą dwubiegunowość), u wielu pacjentów depresyjnych klinicyści, w razie wątpliwości, wciąż muszą polegać na własnej ocenie diagnostycznej na podstawie wskaźników takich jak m.in.: wywiad rodzinny w kierunku manii lub choroby afektywnej dwubiegunowej, diagnostyka początku patologii, duża nawrotowość, obecność objawów psychotycznych, stany mieszane, szybki początek i remisja epizodów, pełna remisja pomiędzy epizodami, temperament (hipertymiczny, cyklotymiczny) oraz odporność na leczenie ${ }^{8}$.

Na potrzeby naszych analiz w kontekście wpływu niedojrzałości psychoafektywnej na małżeństwo, warto przytoczyć jeszcze jeden podział wprowadzony przez przywołanych już wyżej włoskich psychiatrów. Mianowicie dokonują oni również rozróżnienia pomiędzy odczuciami i emocjami. Odczucia to afektywne stany świadomości, które obejmują emotywne lub relatywne zdolności psychiczne

7 Por. A. Bilikiewicz (red.), Psychiatria - podręcznik dla studentów medycyny, Warszawa 2011, s. 324; K. Kucharczy , A. Pawlak, A. Kacprzyk-Straszak, Depresja i zaburzenia nastroju - nie bójmy się o tym mówić, s. 1-2, https://www. researchgate.net/publication/328662600_Depresja_i_zaburzenia_nastroju_-_nie_ bojmy_sie_o_tym_mowic_(dostęp 15.02.2020 r.).

${ }^{8}$ Por. J. Angst, V. Ajdacic-Gross, W. Rössler, Klasyfikacja zaburzeń nastroju, Psychiatria Polska 49 (2015) nr 4, s. 669. 
podmiotu, ściśle związane z przeszłością, myślami i obrazami. Są dość głębokie i trwałe. Emocje natomiast to złożone psychosomatyczne procesy, w których występuje, mniej lub bardziej wyraźny, psychiczny i behawioralny element somatyczny. Mają one bezpośredni związek $\mathrm{z}$ bodźcami środowiskowymi, z nagłym, krótkotrwałym i różnym nasileniem. Z semantycznego punktu widzenia odczucia odróżnia się od emocji, ponieważ uważa się je za trwalsze oraz posiadające większy zasób myśli

\section{Typ melancholijny, depresyjny}

Najczęściej spotykanym zaburzeniem nastroju i najbardziej zróżnicowanym jest depresja. Spektrum nastroju depresyjnego jest ukonstytuowane na przeważających odczuciach smutku, poczuciu braku szczęścia, melancholii, bólu, pesymizmu, poczuciu winy, przygnębienia. Zazwyczaj towarzyszy mu zahamowanie i spowolnienie czynności życiowych zarówno psychicznych jak i fizycznych. Zjawiskami towarzyszącymi tego rodzaju zaburzeniom nastroju są zaburzenia snu, spadek apetytu, poczucie zmęczenia, problemy poznawcze ze szczególnym odniesieniem do trudności w koncentracji, skupienia uwagi, pamięci, uczenia się, depresyjne myśli (opuszczenia, braku wartości, samodestrukcji, winy, braku nadziei). Takie zjawiska mogą przybierać cechy charakterystyczne dla majaczenia, bredzenia czy nawet absurdalnych urojen ${ }^{10}$.

G. Zuanazzi1 ${ }^{11}$ wyszczególnia trzy aspekty melancholii: ból moralny, urojenia i skłonność do samobójstw. Ból moralny to obniżenie nastroju. Smutek przybiera mroczną postać, monotonię, bezgraniczną głębię, odporność na zewnętrzne bodźce; a to nadaje relacjom

\footnotetext{
9 Por. T. Cantelmi, M. Aiello, La persona umana: concetto psicologico..., s. 98. 10 Por. TAmżE, s. 97.

11 Wybitny psychiatra, dyrektor Szpitala Psychiatrycznego w Veronie, profesor w Instytucie Psychiatrii Uniwersytetu Mediolańskiego, profesor psychologii i psychopatologii w Papieskim Instytucie Jana Pawła II, biegły sądowy przy Trybunale Roty Rzymskiej.
} 
melancholika zupełnie inny ton niż ten, który można zdiagnozować u neurotyka ${ }^{12}$, którego ból wydaje się mniej „autentyczny”, bardziej żałosny, zabarwiony pragnieniem konfrontacji lub po prostu pragnieniem współczucia. Melancholik jest głęboko doświadczany przez bolesne poczucie pogardy dla samego siebie, niemocy, niezdolności, bezproduktywności, nie tylko na polu działania, jako konsekwencja zahamowania psychicznego i motorycznego, ale także w sferze moralnej. Stąd poczucie braku godności dla samego siebie i poczucie winy. Jednocześnie wspomniany autor zwraca uwagę, że w przypadku melancholika, poczucie winy różni się od skrupułów nie tyle silnym samooskarżaniem się lub mocnymi udrękami, ale raczej absolutną pewnością ewidentnie fałszywego osądu samego siebie oraz braku jakiejkolwiek świadomości zaburzeń psychicznych. Podmiot czuje, że jego witalność została zmiażdżona przez grzech; ma prawie fizyczne doświadczenie ciężaru winy; czuje się zagubiony, opuszczony; w jego horyzoncie całkowitej ciemności wyłania się nieunikniona wieczna ofiara. Ideom grzechu, braku własnej godności, skażenia, odpowiada oczekiwanie na karę, jedyne zdarzenie, które w jakiś sposób może pozwolić na rozwiązanie winy i powrót do życia. Możliwość ukarania

12 B.G. Charlton dzieli stany depresyjne na: 1) melancholia - klasyczna, ciężka postać depresji endogennej, możliwe występowanie objawów psychotycznych, takich jak omamy, urojenia, zaburzenia myślenia, katatonia i spowolnienie psychoruchowe; 2) neurotyzm - rodzaj cechy wrodzonej utrzymującej się przez całe życie. Częste nieprzyjemne wahania nastroju, poczucie winy, niska samoocena, drażliwość, nieśmiałość, emocjonalność; 3) złe samopoczucie - stan wyczerpania podobny do występującego w chorobach infekcyjnych, poczucie stałego zmęczenia (TAT - tired all time), obniżenie nastroju jest wtórne; 4) depresja z demotywacją - zmniejszenie nasilenia pozytywnych emocji, niemożność lub upośledzenie doznawania przyjemności, z tego wynika brak zainteresowania życiem; 5) choroba afektywna sezonowa - obniżenie nastroju wyraźnie związane ze zmniejszeniem ilości światła słonecznego, charakterystyczna nadmierna senność, zwiększony apetyt, drażliwość, męczliwość. Por. B.G. Charlton, A model for self-treatment of four sub-types of symptomatic "depression" using non-prescription agents: neuroticism (anxiety and emotional instability); malaise (fatigue and painful symptoms); demotivation (anhedonia) and seasonal affective disorder "SAD", Med Hypotheses 72 (2009), s. 1-7; Ł. ŚwIĘCICKI, Leczenie zaburzeń nastroju. Taktyka i strategia, Wrocław 2019, s. 5. 
lub samoukarania jest pojmowana jako „łaska”, jest przekonany, że był „zawsze winny”"

Kliniczny obraz stanu melancholijnego (nazywanego dużym zaburzeniem depresyjnym), jest zdominowany także przez ból moralny i tzw. taedium vitae, któremu towarzyszą uporczywe i stałe niezdolności podmiotu do działania, połączone z obrzydzeniem do życia. Nie brakuje w nich poczucia bezużyteczności, utraty własnej wartości, poczucia winy. Osoba taka jest milcząca, nie jest w stanie pracować, nie ma zainteresowań seksualnych, nie odczuwa przyjemności (anhedonia), ma myśli lub intencje samobójcze. Zmiana nastroju wiąże się ze zmianą funkcji poznawczych. Koncentracja jest słaba i nietrwała, myśl wydaje się uboga w treść, niezbyt produktywna, powolna w rozwoju, zahamowana. Czasami pojawiają się urojenia winy, katastrofy życiowej, negacja otaczającej rzeczywistości. Pojawia się ewidentna niepewność, abulia, brak zainteresowania i brak własnej inicjatywy, trudności z wykorzystaniem posiadanej wiedzy i pamięci. Zwykle osoby te mają spowolnioną aktywność ruchową, zaniedbują siebie w ubieraniu i pielęgnacji osobistej. Często występują zaburzenia snu, apetytu i wspomniane wyżej zmniejszone pożądanie seksualne. Pacjent boleśnie przeżywa i narzeka na swój $\operatorname{stan}^{14}$. W stanach bardzo zaawansowanych przyjmuje postać samooskarżeń i urojeń winy, ruiny materialnej, czy też w krańcowej postaci - urojeń nihilistycznych. Takie zaawansowanie procesu depresyjnego powoduje myśli i tendencje samobójcze ${ }^{15}$. Zdaniem profesora G. Zuanazzi, takie złudzenia są związane z destrukcją osobowości, absolutnym przekonaniem o katastrofalnych wydarzeniach. Poczucie to odnosi się głównie do niepewnego stanu rodziny (ale nie zawsze), za który pacjent przypisuje sobie odpowiedzialność, lub który uważa za nieodwracalny w wyniku czynników zewnętrznych. Przyszłość jest beznadziejna,

\footnotetext{
13 Por. G. ZuAnazzI, Psicologia e psichiatria nelle cause matrimoniali canonice, Studii Giuridici XCIII, Città del Vaticano 2012, s. 198.

14 Por. TAmże, s. 197-198.

15 Por. K. Kucharczyk, A. Pawlak, A. Kacprzyk-Straszak, Depresja i zaburzenia nastroju..., s. 3; H. SЕ̨K, Psychologia kliniczna, t. 2, Warszawa 2012, s. 101-102.
} 
nie ma możliwości jej zaradzenia, wszystko jest stracone, najdrożsi zginą $^{16}$. Kanoniści, jak i biegli powoływani w procesach o nieważność małżeństwa, powinni zwracać szczególną uwagę, aby tego zjawiska nie mylić z pesymizmem, który jest jedynie nieufnością do życia i przeznaczenia, niekorzystną oceną wydarzeń i okoliczności.

Światowej sławy psychiatra H. Ey stoi na stanowisku, że melancholijność jest osadzona w zdekonstruowanej czasowości, która straciła impet ku przyszłości i jest nieustannie pchana ku przeszłości. Czas jest i musi być dla melancholika perspektywą śmierci ${ }^{17}$. Myśli o śmierci są stale obecne w świadomości melancholików, a skłonność do samobójstw jest bardzo realna. Samobójstwo może zostać popełnione podczas raptus melanconicus, gwałtownego impulsu, który dramatycznie przełamuje stan zahamowania: w tym przypadku morderstwo-samobójstwo z litości nie należy do rzadkości, zwłaszcza jeśli istnieją urojeniowe idee destrukcji, końca świata lub porzucenia (typowe jest samobójstwo popełniane przez matki, które zabijają jednocześnie swoje dzieci, aby uchronić je przed większym cierpieniem, katastrofalnym losem). Niekiedy samobójstwo jest dokonywane przy pełnej świadomości sumienia. Niebezpieczeństwo jest zawsze obecne, zwłaszcza w początkowej fazie procesu chorobowego i na początku remisji, czyli wtedy, gdy zahamowanie nie jest jeszcze w pełni rozwinięte lub zaczyna słabnąćc ${ }^{18}$.

W opisie przedmiotowych przypadków zwraca się również uwagę na możliwość występowania tzw. zespołu Cotarda, nazywanego „syndromem chodzącego trupa”, polegającego na psychicznym odrzuceniu (wyparciu) części swego ciała: serca, żołądka lub innego organu. Odrzucenie własnych organów, a niekiedy całego ciała, przyjaciół, świata, łączy się z silnym przekonaniem, że nie jest się w stanie umrzeć, będąc przeznaczonym na wieczne cierpienia ${ }^{19}$.

\footnotetext{
16 Por. G. Zuanazzi, Psicologia e psichiatria nelle cause matrimoniali..., s. 198-199.

17 Por. H. Ey, P. Bernard, Ch. Brisset, Manuale di psichiatria, Milano 1977, s. 275.

18 Por. G. Zuanazzi, Psicologia e psichiatria nelle cause matrimoniali..., s. 200.

19 Por. J. KowAlski, Zespół Cotarda, http://neuropsychologia.org/zespol-cotarda (dostęp 20.02.2021 r.); G.E. BERrios, R. LuQue, Cotard's syndrome: analysis of 100
} 
Mimo istnienia wielu teorii z rzetelnym materiałem dowodowym, które próbowały wyjaśnić pochodzenie depresji, nadal nie ma jednoznacznej odpowiedzi na pytanie, skąd się bierze. Pewne jest, iż depresja jest wynikiem współdziałania różnych czynników. Dwa główne nurty, które stanowią podstawę wiedzy co do powstawania zaburzeń depresyjnych, to podejście genetyczne i psychodynamiczne (koncepcja behawioralna, stresujące wydarzenia życiowe, relacje interpersonalne $)^{20}$.

W podejściu genetycznym dużą rolę w określaniu stopnia podatności człowieka na depresję odgrywają geny. Krewni pierwszego stopnia pacjentów cierpiących na depresję są od dwóch do pięciu razy bardziej podatni na wystąpienie depresji niż reszta społeczeństwa ${ }^{21}$.

W podejściu psychodynamicznym w pierwszej kolejności należy zwrócić uwagę na koncepcję behawioralną. Według tego stanowiska, osoby tracą motywację do działania na skutek negatywnych doświadczeń z przeszłości i nabierają przekonania, że ich działania są bezskuteczne. Związane jest to z wykształceniem się szczególnego stylu atrybucji, który prowadzi do obniżenia samooceny i pasywności, zaniku motywacji do działania, uogólnionego pesymizmu ${ }^{22}$.

cases, Acta Psychiatrica Scandinavica 91 (1995) nr 3, s. 185-188; H. Debruyne, M. Portzky, F. Van den Eynde, K. Audenaert, Cotard's syndrome: a review, Current Psychiatry Reports 11 (2009) nr 3, s. 197-202.

20 Por. K. Kucharczy , A. Pawlak, A. Kacprzyk-Straszak, Depresja i zaburzenia nastroju..., s. 13-14.

21 Por. M. Seligman, E. Walker, D. Rosenhan, Psychopatologia, Warszawa 2001, s. 285. Badania bliźniąt dowodzą, że depresja dziedziczy się w 40-50\%. Najprawdopodobniej w grę wchodzą interakcje wielu genów, z których każdy ma słabe działanie. Niektóre geny znajdują swoją ekspresję tylko w szczególnych okolicznościach (interakcje pomiędzy genem a środowiskiem). Na przykład, niektóre allele genu transportera serotoniny zwiększają ryzyko zachorowania na depresję, ale tylko u tych osób, które doświadczają niekorzystnych zdarzeń życiowych. Sama obecność alleli (bez niekorzystnych zdarzeń w życiu) nie spowoduje zachorowania. Por. K. Marwick S., Birrell K., Psychiatria, Wrocław 2014, s. 153.

22 Por. A. Bilikiewicz, J. Landowski, P. RadziwiŁŁowicz, Psychiatria. Repetytorium, Warszawa 2008, s. 93. 
Osoby, u których rozwinęła się depresja, częściej niż inne, w okresie poprzedzającym są narażone na większą liczbę niekorzystnych wydarzeń życiowych i różnego rodzaju strat. W przypadku zaburzeń depresyjnych nawracających dotyczy to szczególnie pierwszych faz. We wczesnym okresie życia wydarzenia stresujące mogą doprowadzić do trwałych zmian funkcji ośrodkowego układu nerwowego, a to bywa czynnikiem predysponującym do późniejszych epizodów zaburzeń afektywnych ${ }^{23}$. Pojawienie się epizodu depresyjnego często poprzedzają niekorzystne wydarzenia życiowe, szczególnie takie, które łączą się z utratą, upokorzeniem (np. żałoba, zerwanie relacji, zwolnienie z pracy). Należy podkreślić, że zdarzenie życiowe samo w sobie nie musi być przyczyną depresji czy zwiększonej podatności na to schorzenie. Bywa tak, że to sama depresja lub nawet tylko zwiększona podatność na nią zwiększa ryzyko doświadczania niekorzystnych zdarzeń w życiu. W kolejnych epizodach zaburzenia depresyjnego nawracającego zdarzenia życiowe odgrywają coraz mniejszą rolę $^{24}$. G. Brown wyodrębnił zespół czynników podatności na depresję w sytuacjach trudnych. Należą do nich: brak oparcia w bliskim w związku, brak stałego zatrudnienia, samotne wychowywanie dzieci, utrata rodzica przed jedenastym rokiem życia ${ }^{25}$. Separacja bądź rozwód rodziców w okresie dzieciństwa zwiększają ryzyko zachorowania na depresję w okresie dorosłości. Częściowo można to wytłumaczyć utratą rodziców, a częściowo chaosem i zamętem w sprawowaniu opieki nad dzieckiem. Również inne przeciwności losu (np. zaniedbanie, wykorzystywanie seksualne, znęcanie się fizyczne) zwiększają nie tylko ryzyko depresji, ale i innych zaburzeń psychicznych ${ }^{26}$.

W modelu interpersonalnym zwraca się uwagę na wpływ podstawowej grupy społecznej, którą jest rodzina, przyjaciele, środowisko pracy. Zła jakość więzi społecznych, zaburzone pełnienie ról, niezadowalające relacje interpersonalne, brak bliskich osób, mogą

\footnotetext{
23 Por. TAmże, s. 94.

24 Por. K. Marwick, S. Birrell, Psychiatria..., s. 153.

25 Por. G. Brown, T. Harris, Social Origins of Depression, London 1978.

26 Por. K. Marwick, S. Birrell, Psychiatria..., s. 153.
} 
być zarówno przyczyną reakcji depresyjnych, jak i konsekwencją depresji ${ }^{27}$. Dziedziczność oraz wychowanie we wczesnym okresie życia kształtują profil osobowości. Okazuje się, że niektóre jej cechy zwiększają ryzyko wystąpienia zaburzeń nastroju. Na przykład tzw. neurotyzm (lękliwość, niepewność, wstydliwość, podatność na stres) wyraźnie sprzyja wystąpieniu depresji jednobiegunowej. Również niektóre zaburzenia osobowości zwiększają ryzyko wystąpienia depresji (np. zaburzenie graniczne osobowości, zaburzenie obsesyjno-kompulsywne). Psychologiczne i somatyczne następstwa przewlekłego stresu mogą z jednej strony zwiększać podatność na depresję, a z drugiej - osłabiać zdolność radzenia sobie z trudnymi, stresującymi zdarzeniami. Niekorzystnie wpływają na depresję takie przewlekłe stresory jak: niedostateczne wsparcie społeczne (np. brak kogoś, komu można się zwierzyć), brak pracy poza domem, opieka nad małym dzieckiem, a także przewlekłe zespoły bólowe i choroby (szczególnie choroba serca i udar mózgu) ${ }^{28}$. Rzecz jasna nie każdy, kto przeżył ciężkie chwile albo był w dzieciństwie źle traktowany, będzie miał depresję. Przeciwnie - zdarza się to niewielu osobom ${ }^{29}$.

Warto dodać, że depresja może wystąpić jako powikłanie chorób somatycznych. Najczęściej objawy depresyjne wiążą się z zaburzeniami hormonalnymi (tarczycy) i przemiany materii, towarzyszą zabiegom chirurgicznym (kardiochirurgicznym), zatruciom, infekcjom (AIDS, wirusowe zapalenie wątroby), niedoborom witamin ${ }^{30}$.

Dystymia to przewlekłe, utrzymujące się dłużej niż dwa lata zaburzenie nastroju. W obrazie klinicznym dystymii dominują takie objawy jak: umiarkowane obniżenie podstawowego nastroju, złe samopoczucie, poczucie ciągłego zmęczenia, ogólnej niesprawności (w tym umysłowej), apatia i anhedonia, niska samoocena. Częstym zjawiskiem jest przewlekły lęk. Zdolność do wykonywania

\footnotetext{
27 Por. H. SĘK, Psychologia kliniczna, s. 113-114.

28 Por. K. Marwick, S. Birrell, Psychiatria..., s. 154.

29 Por. Zaburzenia nastroju, https://cnx.org/contents/co3wu-B_@1.1:Zj5vy_ rd@2/15-7-Zaburzenia-nastroju (dostęp 15.02.2020 r.).

30 Por. H. SĘK, Psychologia kliniczna, s. 106.
} 
podstawowych obowiązków (domowych, zawodowych) jest często zachowana, towarzyszy im jednak brak satysfakcji. U części chorych obniżenie nastroju idzie w parze ze wzmożonym napięciem emocjonalnym, drażliwością, stanami dystrofii z tendencją do obwiniania innych za zły stan zdrowia; mogą pojawić się postawy roszczeniowe wobec leczących $z$ powodu niesatysfakcjonujących efektów terapii ${ }^{31}$.

Cyklotymia to utrzymujące się przez długi czas (często przez całe życie) wahania nastroju i aktywności w postaci łagodnych stanów subdepresyjnych oraz hipomanii, występujące zwykle naprzemiennie, niekiedy oddzielone dłuższymi, kilkumiesięcznymi okresami normalnego samopoczucia. Zmiany nastroju na ogół nie są zależne od bieżących wydarzeń życiowych, pojawiają się spontanicznie. Okresy subdepresji są negatywnie odczuwane przez osoby je przeżywające, hipomania jest zwykle odbierana jako stan znakomitego zdrowia. Często występujące zmiany nastroju mogą dezorganizować aktywność i zaburzać realizację planów życiowych. U części osób powikłaniem cyklotymicznym wahań nastroju jest nadużywanie alkoholu i/ lub leków, niekiedy prowadzące do uzależnienia ${ }^{32}$.

\section{Typ maniakalny}

W odniesieniu do zaprezentowanego powyżej typu melancholijnego typ maniakalny jest przeciwieństwem depresji i obejmuje nieuporządkowaną euforię, niestabilność emocjonalną, przesadę werbalną, ekstrawagancję, nieuporządkowaną wylewność. Obrazem zmian nastroju maniakalnego jest zatem struktura całkowicie odmienna, różna od doświadczeń depresyjnych tak bardzo, że możemy mówić o zahamowaniach i braku zahamowań, spowolnieniu i przyśpieszeniu, przygnębieniu i euforii, niskiej samoocenie i wysokim ego, zmniejszonym libido i hiperseksualności ${ }^{33}$. Wyraźna jest zatem antynomia między stanem maniakalnym a depresyjnym. Słynny

31 Por. A. Bilikiewicz (red.), Psychiatria..., s. 337-338.

32 Por. TAMżE, s. 338.

33 Por. T. Cantelmi, M. Aiello, La persona umana: concetto psicologico..., s. 97. 
psychiatra L. Binswanger ujmując to $\mathrm{z}$ fenomenologicznej perspektywy stwierdza: „jeśli w formie maniakalnej przestrzeń staje się szeroka i nieskończona, to w melancholii jest ciasna, ograniczona i zamknięta; w maniakalnej czas jest krótki, w melancholicznej jest długi; w maniakalnej rytm przeżywanego doświadczenia jest szybki, w melancholicznej jest powolny; jeśli w pierwszej z nich świat jest efemeryczny (niespójny, lekki, miękki) i przejrzysty, to w drugiej z nich jest twardy, ciężki, sztywny, czarny i ciemny; w maniakalnej ruchomy, w depresyjnej stały. O ile w manii można mówić o dynamicznej formie istnienia, w melancholii jest ona statyczna, mocna, bez wyjścia; w typie maniakalnym występują skoki biograficzne, intelektualne i społeczne; w melancholijnym biografia, przemyślenia, relacje z otaczającym światem nie istnieją. W manii istnieje konkretna, okrągła linia życia, w melancholii punkt życia; w manii człowiek jest pochłonięty działaniem, w depresji winą"34.

W typie maniakalnym obserwuje się przejście ze stanu euforii w nastrój irytacji, podmiot może stawać się agresywny w słowach lub czynach. Diagnoza takich przypadków jest bardzo trudna, gdyż podmiot zwykle nie jest świadomy patologicznego charakteru tego zjawiska w sobie ${ }^{35}$. Myśl zmienia się pod względem formy i treści: obserwuje się intelektualną nielogiczność, ze słabą zdolnością do krytyki, niekonsekwencje, urojenia wielkości, władzę, erotyzm, doświadczenia pseudo-mistyczno-religijne. Rozproszenia uwagi wpływają na pamięć. Nie brakuje błędów percepcji, zmian w czynnościach, niewłaściwych próśb, rozproszenia, brak hamulców moralnych (okresowe spożywanie alkoholu, dewiacje seksualne, wykroczenia społeczne). Na poziomie somatycznym obserwuje się bezsenność i utratę wagi (nawet przy wzroście apetytu). Świadomość choroby jest ograniczona lub nieobecna; podmiot doświadcza dobrego samopoczucia. Przypadki choroby, które zazwyczaj występują nagle, zwykle ustępują w ciągu kilku tygodni. Farmakologia notuje dobre reakcje pacjentów na leki. Jeśli zmiana nastroju nie jest szczególnie dotkliwa, mówimy

34 Por. L. Binswanger, Melanconia e mania, Torino 1971, s. 109.

35 Por. T. Cantelmi, M. Aiello, La persona umana: concetto psicologico..., s. 97. 
o epizodzie hipomanii, którego cechy imperatywności, kreatywności, żywiołowości i oryginalności nie są postrzegane jako patologiczne przez otaczające środowisko ${ }^{36}$.

Osoba z chorobą afektywną dwubiegunową doświadcza częstych i nasilonych wahań nastroju od depresji po manię (w przeciwieństwie do zaburzeń depresyjnych, które cechuje permanentnie obniżony nastrój). W trakcie epizodu maniakalnego niektórzy doświadczają podwyższenia nastroju do granicy euforii, stają się bardzo gadatliwi, niekiedy sami zagadują do obcych. Inni stają się rozdrażnieni, na wszystko się skarżą albo czynią przykre uwagi. Osoba w manii może mówić bardzo szybko i głośno, ma tzw. gonitwę myśli, przeskakując z jednego tematu na drugi. Łatwo się rozprasza, co sprawia, że rozmowa $\mathrm{z}$ nią jest bardzo trudna. Ma bardzo wysokie mniemanie o sobie i jest bardzo pewna siebie, choć te uczucia mogą być zupełnie nieuzasadnione. Często jednocześnie rozpoczyna wiele przedsięwzięć (np. kilka czasochłonnych projektów w pracy) nie wykazując przy tym potrzeby snu; niektórzy mogą nie spać przez kilka dni z rzędu. Lekkomyślnie angażuje się też w aktywności, które dają przyjemność, ale mogą mieć przykre lub niebezpieczne konsekwencje, np. wydaje fortunę na niepotrzebne rzeczy, prowadzi auto łamiąc przepisy ruchu drogowego, impulsywnie inwestuje pieniądze, uprawia hazard albo ryzykowny seks z nieznajomymi. Pacjenci w manii zwykle nie przyjmują do wiadomości, że są chorzy i twierdzą, że nie potrzebują leczenia. Mogą być jednak hospitalizowani w efekcie ryzykownych zachowań (aspołecznych, nielegalnych albo fizycznie zagrażających innym) jakie towarzyszą temu epizodowi ${ }^{37}$.

W odróżnieniu od typu melancholijnego, typ maniakalny albo epizod manii, występuje rzadziej niż różne odmiany depresji. Niewielkie nasilenie manii, zwane stanem hipomaniakalnym, gdy występuje w dwubiegunowych zaburzeniach afektywnych, jest niezwykle pozytywnie oceniane przez pacjentów, jest bowiem stanem przyjemnym

\footnotetext{
36 Por. G. Zuanazzi, Psicologia e psichiatria nelle cause matrimoniali..., s. 200.

37 Por. Zaburzenia nastroju, https://cnx.org/contents/co3wu-B_@1.1:Zj5vy_ rd@2/15-7-Zaburzenia-nastroju (dostęp 15.02.2020 r.).
} 
i twórczym. Jednak w pełni rozwinięty stan maniakalny ma wyraźny charakter kliniczny ${ }^{38}$. Hipomanię można rozpoznać, gdy dolegliwości utrzymują się powyżej czterech dni, manię natomiast dopiero po tygodniu występowania jej objawów ${ }^{39}$. Wskazują na to, jak już wyżej podkreślono, objawy niespożytej energii, nieuzasadnionego poczucia wszechmocy, zwiększone zainteresowanie sferą seksualną. Przy skrajnym nasileniu manii następuje rozerwanie toku myśli i urojenia wielkościowe. W stanach mieszanych mogą także występować myśli samobójcze i poczucie winy. A contrario, w odchyleniach depresyjnych pojawiają się ponadto zaburzenia regulacji rytmów biologicznych, czynności układu autonomicznego i przemiany materii. Chorzy skarżą się na brak apetytu, utratę wagi, skrócenie snu, obniżenie libido, zmęczenie, bóle, zaburzenia menstruacji i potencji ${ }^{40}$. Dlatego też przywoływany już wyżej, słynny psychiatra H. Ey, uważa, że kryzys maniakalny przedstawia deficyt wyższych struktur (wartości) i akcentuje aspekt uwolnienia niższych popędów ${ }^{41}$.

\section{Ocena kanoniczna zjawiska}

Dla celów orzekania w sprawach kanonicznych należy przede wszystkim zwrócić uwagę na zaburzenia afektywne, w których przerwy między manifestacją patologii a normalnością są bardzo krótkie. Tendencja ta występuje częściej u pacjentów z chorobą afektywną dwubiegunową niż u tych, którzy okresowo cierpią na jednolite zaostrzenia, maniakalne lub melancholijne. W tym przypadku - jak twierdzi G. Zuanazzi - chorobę można praktycznie uznać za ciągłą,

\footnotetext{
38 Por. K. Kucharczy , A. Pawlak, A. Kacprzyk-Straszak, Depresja i zaburzenia nastroju..., s. 3; H. SĘK, Psychologia kliniczna, s. 101-102.

39 Por. T. NĘCKI, Zaburzenia nastroju (afektywne): przyczyny i objawy wahań nastroju, https://www.poradnikzdrowie.pl/zdrowie/psychiatria/zaburzenia-nastroju-afektywne-przyczyny-i-objawy-wahan-nastroju-aa-oqPW-bd55-57RP.html, (dostęp 15.02.2020 r.).

40 Por. K. Kucharczyk, A. Pawlak, A. Kacprzyk-Straszak, Depresja i zaburzenia nastroju..., s. 3; H. SЕ̨K, Psychologia kliniczna, s. 101-102.

41 Por. H. Ey, P. Bernard, Ch. Brisset, Manuale di psichiatria, Milano 1977, s. 247.
} 
zwłaszcza gdy, jak to często bywa, w krótkich odstępach czasu występują łagodniejsze, ale stabilne zjawiska psychopatologiczne. $\mathrm{Na}$ ogół nasilają się one wraz z upływem lat i powtarzaniem się nawrotów. Można zauważyć, że bardzo częste powtarzanie się kryzysów uniemożliwia podmiotowi normalne życie i poważnie zaburza życie małżeńskie ${ }^{42}$. Zaburzenia nastroju w formach, w jakich moga się wyrażać (zaburzenia głębokiej depresji, zaburzenia maniakalne, choroba afektywna dwubiegunowa typu I i typu II) można scharakteryzować postępującą utratą poczucia rzeczywistości, a tym samym ambiwalencją władz psychicznych podmiotu, która zaburza znacznie lub całkowicie proces krytycznej oceny oraz wolnego i świadomego podjęcia praw i obowiązków małżeńskich ${ }^{43}$.

Oceniając pod kątem kanonicznym przypadki zaburzeń nastroju, należy mieć świadomość, że w ciężkich zespołach depresyjnych można zaobserwować spowolnienie, a nawet zniekształcenie funkcji poznawczych oraz zahamowanie procesów wolitywnych; stąd u takich osób mogą występować mankamenty rozeznania oceniającego. Należy jednak $\mathrm{z}$ naciskiem podkreślić, że symptomatologia jest obecna tylko w krytycznych fazach; poza nimi pacjent jest normalny, z wyjątkiem przypadków, w których fazy są tak bliskie, że nie pozwalają na całkowite ustąpienie objawów. W związku z tym, dla celów procesu kanonicznego ważne będzie rozważenie intensywności, czasu trwania i częstotliwości epizodów. Nawet w łagodnych postaciach psychoza maniakalno-depresyjna może determinować stopniowe pogarszanie się jakości życia indywidualnego, małżeńskiego i rodzinnego ${ }^{44}$. Osoba, która wyraża zgodę małżeńską, powinna rozumieć swój własny świat emocjonalny oraz odnajdywać się w pełnej wolności wewnętrznej, którą osiąga się przy odpowiedniej kontroli nad swoimi emocjami, w której zgodnie przeplatają się zdolności intelektualne i wolitywne ${ }^{45}$. Nie należy pomijać oceny relacji uczuciowej

\footnotetext{
42 Por. G. Zuanazzi, Psicologia e psichiatria nelle cause matrimoniali..., s. 205.

43 Por. T. Cantelmi, M. Aiello, La persona umana: concetto psicologico..., s. 97-98.

44 Por. G. Zuanazzi, Psicologia e psichiatria nelle cause matrimoniali..., s. 206.

45 Por. T. Cantelmi, M. Aiello, La persona umana: concetto psicologico..., s. 99.
} 
i międzyludzkiej, gdyż duże znaczenie w zaburzeniach nastroju ma umiejętność podmiotu w przeżywaniu uczuć i emocji. Należy zwrócić także uwagę, że szczególnie niebezpieczną dla małżonka i dzieci może stać się osoba $\mathrm{z}$ depresją ukierunkowaną na destrukcję, zdolną do zabójstwa z pobudek altruistycznych ${ }^{46}$.

Podobne kryteria obowiązują w przypadku kryzysów maniakalnych, z zastrzeżeniem, że zanik objawów może następować stopniowo, pozostawiając po sobie długą fazę psychicznego niepokoju i niestabilności nastroju. Czasami zanika tylko jeden z głównych objawów, a inne utrzymują się nadal. Przykładowo, mogą zaniknąć objawy urojeniowe, ale nadal manifestuje się podrażniony nastrój, brak hamulców moralnych, brak samokrytyki, brak satysfakcji w dzieleniu się pasjami itd. ${ }^{47}$ Kanonista powinien ocenić, czy w wyniku działań zaburzonej osobowości doszło do niezaistnienia diadycznej relacji międzyosobowej między małżonkami ${ }^{48}$.

Warto ponadto zasygnalizować, że w epizodach hipomanii i osobowości hipertymicznych ze względu na wysoką aktywność bodźców nastrojowych, euforię, podmiot wykazuje brak krytycznej oceny rzeczywistości, często dokonuje pochopnych wyborów, nie zastanawia się w konkretnych przypadkach nad istotnymi obowiązkami małżeńskimi. Jeśli chodzi o życie małżeńskie, hipomaniakalność stwarza w oczywisty sposób poważne problemy we wspólnym życiu małżeńskim; w ten sam sposób osoby dotknięte tym zaburzeniem są źródłem rodzinnego dyskomfortu i cierpienia dla współmałżonka i pozostałych członków rodziny ${ }^{49}$.

Należy jednak zdawać sobie sprawę, że z drugiej strony, gdy występują długie przerwy w objawach zaburzeń (miesiące lub lata), podmiot może wykazać całkowity powrót do normalności i będzie wtedy mógł dokonywać wolnych i świadomych wyborów oraz wypełniać

\footnotetext{
46 Por. TAmŻE, s. 98.

47 Por. G. Zuanazzi, Psicologia e psichiatria nelle cause matrimoniali..., s. 206-207.

48 Por. T. Cantelmi, M. Aiello, La persona umana: concetto psicologico..., s. 98.

49 Por. G. ZuAnazzi, Psicologia e psichiatria nelle cause matrimoniali..., s. 207.
} 
podstawowe obowiązki małżeńskie ${ }^{50}$. Tworzenie harmonii odpowiedzialnego życia małżeńskiego niekoniecznie i nie zawsze musi kończyć się epizodami kryzysowymi. Oczywiście, zdaniem T. Cantelmi i M. Aiello każda forma komunikacji z osobą dotkniętą zaburzeniami nastroju zakłada ryzyko zaskoczenia, trudności w dialogu, braku racjonalnego i konsekwentnego planowania wspólnego życia, braku krytycznego rozeznania oceniającego, tendencji do agresywnego i gwałtownego zachowania ${ }^{51}$. Absurdem byłoby jednak orzekanie niezdolności natury psychicznej do zawarcia małżeństwa tylko dlatego, że za 4, 5 lub 10 lat może dojść do nowego ataku depresyjnego. Tym bardziej, że znaczący odsetek pacjentów ma tylko jeden epizod w całym swoim życiu ${ }^{52}$.

Ocena zaburzeń afektywnych w kontekście kanonicznym musi przede wszystkim uwzględniać to, że jeśli mają one charakter okresowy, to pacjenci przechodzą przez kryzys o bardzo zmiennym nasileniu, przeplatany okresami, niekiedy bardzo długimi, powrotu do normalnej stabilizacji; po drugie, że zwykle ujawniają się wyraźnie we wczesnej dorosłości, kiedy małżeństwo zostało już zawarte. W praktyce klinicznej spotyka się przypadki manii lub częściej melancholii - o czym zasygnalizowano już wyżej - które pojawiają się tylko raz w życiu i zanikają na dłużej niż kilka miesięcy, a także nawracają po różnym czasie. Zauważa się więc nawroty manii lub melancholii, które powtarzają się po okresie poprawy, oddzielone krótkimi lub długimi okresami stabilizacji psychicznej, podczas których pacjent wraca do normalnego stanu ${ }^{53}$.

Przy formułowaniu oceny zdolności do podjęcia istotnych obowiązków małżeńskich nie należy zapominać także o możliwości powrotu do zdrowia, jaką oferują nowoczesne terapie, w tym terapie farmakologiczne. Przykładowo, kryzys melancholijny nie wybucha nagle, ale zwykle poprzedzony jest okresem złego samopoczucia,

\footnotetext{
50 Por. TAmże, s. 205.

51 Por. T. Cantelmi, M. Aiello, La persona umana: concetto psicologico..., s. 98.

52 Por. G. Zuanazzi, Psicologia e psichiatria nelle cause matrimoniali..., s. 205-206.

53 Por. G. Zuanazzi, Psicologia e psichiatria nelle cause matrimoniali..., s. 204-205.
} 
nieufności, rozpaczy; osoba czuje się zmieniona w głębi swojej duszy, przejawia udręki moralne, których już doświadczyła i odczuwa ich rychły powrót. Dlatego melancholik, poza szczególnymi i wyjątkowymi przypadkami, daje niezbędny czas na podjęcie odpowiednich działań terapeutycznych ${ }^{54}$.

\section{Zakończenie}

Podsumowując, warto zwrócić uwagę na dwa aspekty. Pierwszy z nich, natury psychologiczno-psychiatrycznej: o zaburzeniu nastroju, można traktować z punktu widzenia zbioru anomalii, w których występuje zaburzenie nastroju. Ale można też podejść do tego z innej strony: zaburzenie nastroju jako symptom (a wtedy wchodzi w grę ogromna ilość zaburzeń, co zmusza do ustalenia, czy zaburzenie nastroju jest elementem pierwszorzędnym albo tylko pochodnym, jak np. w alkoholizmie).

Drugi aspekt natury jurysprudencyjnej: przed wejściem w życie KPK z 1983 r. wielokrotnie dyskutowano, czy takie lub inne zaburzenie powoduje niezdolność psychiczną czy nie. Następnie zaczęto od tego modelu powoli odchodzić. Obecnie bardzo często część in iure wyroków rotalnych przytacza jedynie zasady ogólne, a następnie dopiero w części in facto dokonuje subsumpcji udowodnionej anomalii i jej skutku uniezdalniającego. To odpowiada też pewnej ewolucji, jaka zachodziła w ostatnich dziesięcioleciach gdy idzie o kryteria oceny tego zjawiska. W alokucjach papieskich z 1987 r. czy 1988 r. $^{55}$ stosowano podejście kategorialne, którego propagatorem był kard. G. Versaldi ${ }^{56}$, wykładowca prawa kanonicznego i psychologii na Papieskim Uniwersytecie Gregoriańskim, bazujący na psychologii, którą

\footnotetext{
54 Por. TAmże, s. 206.

55 Por. Joannes Paulus II, Allocutio ad Rotae romanae, AAS 79 (1987), s. 1453-1459; JoAnnes Paulus II, Allocutio ad Rotae romanae, AAS 80 (1988), s. 1178-1185.

56 Por. G. Versaldi, Momentum et consectaria Allocutionis Ioannis Pauli II ad Auditores Romanae Rotae diei 5 februarii 1987, Periodica 77 (1988), s. 122; G. VerSALDI, Elementa psychologica matrimonialis consensus, Periodica 71 (1982), s. 179-209 i $231-253$.
} 
stosował L.M. Rulla ${ }^{57}$ w Instytucie Psychologii tegoż Uniwersytetu. Na płaszczyźnie kanoniczno-procesowej Instrukcja Dignitas connubii stosuje już podejście dynamiczne ${ }^{58}$ wyrażone w art. $209 \$ 2$. Za racjami aktualnej metody jurysprudencyjnej przemawia ponadto fakt, że poszczególne zaburzenia psychiczne zazwyczaj nie występują jako samoistne. $\mathrm{Z}$ reguły mamy do czynienia $\mathrm{z}$ sytuacjami kompleksowymi, które wymagają też kompleksowej oceny. Konkludując, zawsze należy mieć na uwadze, że nie dana anomalia uniezdalnia jako taka, ale to podmiot - dotknięty daną anomalią - może być (lub nie być) niezdolny do podjęcia istotnych obowiązków małżeńskich.

\section{References}

\section{Źródła}

Dec c. Doran, 4.03.1993, RRDec., vol. LXXXV, s. 108-120.

Dec. c. Bruno, 31.01.1997, RRDec., vol. LXXXIX, s. 70-87.

Dec. c. Turnaturi, 20.02.1998, RRDec., vol. XC, s. 84-99.

Dec. c. Alwan, 13.02.1997, RRDec., vol. LXXXIX, s. 88-102.

Dec. c. BURKe, 12.12.1996, RRDec., vol. LXXXVIII, s. 803-817.

Dec. c. Civili, 19.06.1996, RRDec., vol. LXXXVIII, s. 468-479.

Dec. c. Monier, 5.02.1999, RRDec., vol. XCI, s. 48-57.

Dec. c. StankiewiCZ, 23.03.2000, RRDec., vol. XCII, s. 249-267.

Dec. c. StankiewicZ, 27.02.2003, RRDec., vol. XCV, s. 107-121.

Joannes Paulus II, Allocutio ad Rotae romanae, AAS 79 (1987), s. 1453-1459.

Joannes Paulus II, Allocutio ad Rotae romanae, AAS 80 (1988), s. 1178-1185.

57 Por. L.M. Rulla, Antropologia della vocazione cristiana, vol. I, Bologna 1997, s. $189-190$.

${ }_{58}$ Por. G. ERLebach, Algunas notas sobre el concepto de inmadurez noógena, Ius Communiones 8 (2020), s. 278-281. 


\section{Literatura}

Angst J., Ajdacic-Gross V., Rössler W., Klasyfikacja zaburzeń nastroju, Psychiatria Polska 49 (2015) nr 4, s. 663-671.

Berrios G. E., LuQue R., Cotard's syndrome: analysis of 100 cases, Acta Psychiatrica Scandinavica 91 (1995) nr 3, s. 185-188.

Bilikiewicz A. (red.), Psychiatria - podręcznik dla studentów medycyny, Warszawa 2011.

Bilikiewicz A., Landowski J., RadziwiŁŁowicz P., Psychiatria. Repetytorium, Warszawa 2008.

Binswanger L., Melanconia e mania, Torino 1971.

Brown G., Harris T., Social Origins of Depression, London 1978.

Calicchio S., Depresja i dystrybucje humoryczne: zrozumienie podstawowych mechanizmów, 2020.

Cantelmi T., Aiello M., La persona umana: concetto psicologico e maturità affettiva, w: A. Amati, L'immaturità psico-affettiva e matrimonio canonico, Studi Giuridici LXXXV, Città del Vaticano 2009.

Charlton B.G., A model for self-treatment of four sub-types of symptomatic „depression" using non-prescription agents: neuroticism (anxiety and emotional instability); malaise (fatigue and painful symptoms); demotivation (anhedonia) and seasonal affective disorder "SAD", Med Hypotheses 72 (2009), s. 1-7;

Debruyne H., Portzky M., Eynde F. Van den, Audenaert K., Cotard's syndrome: a review, Current Psychiatry Reports 11 (2009) nr 3, s. 197-202.

ErLebach G., Algunas notas sobre el concepto de inmadurez noógena, Ius Communiones 8 (2020), s. 265-292.

Ey H., Bernard P., Brisset Ch., Manuale di psichiatria, Milano 1977.

KowAlski J., Zespół Cotarda, http://neuropsychologia.org/zespol-cotarda (dostęp 20.02.2021 r.).

Kucharczyk K., Pawlak A., Kacprzyk-Straszak A., Depresja i zaburzenia nastroju - nie bójmy się o tym mówić, https://www.researchgate.net/publication/328662600_Depresja_i_zaburzenia_nastroju_-_nie_bojmy_sie_o_tym_ mowic (dostęp 15.02.2020 r.).

Luigia M., Disturbi dell'umore. Sintomi, cura e classificazione, https://www.ospedalemarialuigia.it/disturbi-dell-umore/cosa-sono-disturbi-umore-dsm-v (dostęp 15.02.2020 r.).

Marwick S., Birrell K., Psychiatria, Wrocław 2014.

NęCKi T., Zaburzenia nastroju (afektywne): przyczyny i objawy wahań nastroju, https://www.poradnikzdrowie.pl/zdrowie/psychiatria/zaburzenia-nastroju-afektywne-przyczyny-i-objawy-wahan-nastroju-aa-oqPW-bd55-57RP.html (dostęp 15.02.2020 r.).

Rulla L.M., Antropologia della vocazione cristiana, vol. I, Bologna 1997.

Seligman M., Walker E., Rosenhan D., Psychopatologia, Warszawa 2001. 
SĘK H., Psychologia kliniczna, t. 2, Warszawa 2012.

Stopani E., Disturbi dell'umore, https://www.ipsico.it/sintomi-cura/disturbi-dellumore (dostęp 15.02.2020 r.).

Św IĘCICKI Ł., Leczenie zaburzeń nastroju. Taktyka i strategia, Wrocław 2019.

Versaldi G., Elementa psychologica matrimonialis consensus, Periodica 71 (1982), S. 231-253.

Versaldi G., Momentum et consectaria Allocutionis Ioannis Pauli II ad Auditores Romanae Rotae diei 5 februarii 1987, Periodica 77 (1988), s. 109-148.

Zaburzenia nastroju, https://cnx.org/contents/co3wu-B_@1.1:Zj5vy_rd@2/15-7-Zaburzenia-nastroju (dostęp 15.02.2020 r.).

Zuanazzi G., Psicologia e psichiatria nelle cause matrimoniali canonice, Studii Giuridici XCIII, Città del Vaticano 2012.

\section{Nota o autorze}

Bartosz Nowakowski - doktor habilitowany nauk prawnych w zakresie prawa kanonicznego, profesor uczelni na Wydziale Nauk Społecznych Uniwersytetu Przyrodniczo-Humanistycznego w Siedlcach, adwokat, członek Consociatio Internationalis Studio Iuris Canonici Promovendo oraz Stowarzyszenia Kanonistów Polskich. 